\title{
A Comparison of Mineralogical and Thermal Storage Characteristics for Two Types of Stone Coal
}

\author{
Chuanchang $\mathrm{Li}^{1}{ }^{1} * \mathbb{C}$, Huan Ma ${ }^{1}$, Baoshan Xie ${ }^{1}$, Bo Zhang ${ }^{1}$, Xinbo Zhao ${ }^{1}$, Mengfan Wang ${ }^{1}$, \\ Zhangxing $\mathrm{He}^{2}$, Wei $\mathrm{Li}^{1, *}$ and Jian Chen ${ }^{1}$ \\ 1 School of Energy and Power Engineering, Changsha University of Science and Technology, \\ Changsha 410114,China; huan_maa@163.com (H.M.); baoshan_xie@126.com (B.X.); \\ zhangbob@stu.csust.edu.cn (B.Z.); 13304823676@163.com (X.Z.); mengfanwang@stu.csust.edu.cn (M.W.); \\ chenjian_513@126.com (J.C.) \\ 2 School of Chemical Engineering, North China University of Science and Technology, \\ Tangshan 063009, China; zxhe@ncst.edu.cn \\ * Correspondence: chuanchangli@csust.edu.cn (C.L.); lwzzgjajie@126.com (W.L.)
}

Received: 29 August 2019; Accepted: 25 September 2019; Published: 29 September 2019

check for updates

\begin{abstract}
Understanding the mineralogical and chemical characteristics of stone coal is imperative for exploring the thermal storage characteristics of stone coal. Two types stone coal $\left(\mathrm{SC}_{\mathrm{wt}}\right.$ and $\mathrm{SC}_{\mathrm{hc}}$ ) were sampled from the pond of a stone coal mine in Henan province (China), and the chemical composition, phase composition, and thermal behavior of the stone coal were investigated. Furthermore, the petrography of the stone coal was studied in detail. The mineral phases of the stone coal were quartz, kaolinite, roscoelite, and goethite, as distinguished by reflected light microscopy and further proven by scanning electron microscope-energy dispersive spectrometer (SEM-EDS). The thermal conductivity of $\mathrm{SC}_{\mathrm{wt}}$ was $0.19 \mathrm{~W} \mathrm{~m}^{-1} \mathrm{~K}^{-1}$, while that of $\mathrm{SC}_{\mathrm{hc}}$ was $0.24 \mathrm{~W} \mathrm{~m}^{-1} \mathrm{~K}^{-1}$. Stearic acid (SA) was blended with $\mathrm{SC}_{\mathrm{wt}}$ and $\mathrm{SC}_{\mathrm{hc}}$ to prepare $\mathrm{SA} / \mathrm{SC}_{\mathrm{wt}}$ and $\mathrm{SA} / \mathrm{SC}_{\mathrm{hc}}$ composites via an impregnation method, respectively. The thermogravimetric (TG) curves show that the loading capacity of $\mathrm{SC}_{\mathrm{hc}}$, at $17.40 \%$, is higher than that of $\mathrm{SC}_{\mathrm{wt}}(16.63 \%)$. The thermal energy storage capacities of SA/SC $\mathrm{Ct}_{\mathrm{wt}}$ and $\mathrm{SA} / \mathrm{SC}_{\mathrm{hc}}$ composites were $29.21 \mathrm{~J} \mathrm{~g}^{-1}$ and $33.02 \mathrm{~J} \mathrm{~g}^{-1}$ according to a differential scanning calorimetry (DSC) analysis. Therefore, $\mathrm{SC}_{\mathrm{hc}}$ is a potential candidate for thermal storage applications due to more obvious thermal storage characteristics, including higher thermal conductivity and loading capacity.
\end{abstract}

Keywords: mineralogical characteristics; thermal storage characteristic; stone coal; vanadium

\section{Introduction}

Nowadays, energy and environmental issues are two major challenges of society, and improving energy utilization efficiency and protecting the environment have received widespread attention [1-6]. It is obvious that inexpensive energy, which is a prerequisite for sustainable economic growth and development, can be produced from coal [7]. Some trace elements in coal also have significant potential for industrial extraction and utilization [8]. With the increasing market demand for high-performance materials and the shortage of high-grade ores, it becomes more and more necessary and urgent to exploit and utilize low-grade resources for high-performance materials [9]. Recently, utilizing low-grade resources to produce high-performance materials and high purity metals has become a research hotspot [10-14].

Stone coal is a combustible, low heat value, high-rank sedimentary rock mainly derived from early Paleozoic bacteria and algae after saponification and coalification in a marine-influenced environment (e.g., epicontinental sea, lagoon, or bay) [15]. It is mainly distributed in southern China, where coal 
resources are scarce, and the reserves are extremely rich. The total reserves of stone coal are $61.88 \mathrm{Gt}$, covering an area of about $30,000 \mathrm{~km}^{2}$ [15]. Because of the simple mining conditions of stone coal and the shortage of coal resources, stone coal resources will be widely used. In recent years, the comprehensive utilization of stone coal resources has developed rapidly [16]. The utilization of stone coal is mainly in four aspects: fuel power (stone coal power generation), building materials, agricultural fertilizer, and refined rare metals [15]. While making full use of the low calorific energy value of stone coal, research on the extraction of vanadium and other associated elements can not only improve the utilization value of stone coal but also provide more urgently needed rare and precious metal materials [16]. Stone coal after the extraction of vanadium also has the potential for producing composite phase change materials. Therefore, the study of the mineralogical characteristics of stone coal is very important. So far, very little information related to the composite phase change materials that use stone coal is available, and only research in vanadium extraction from stone coal has been conducted. Stone coal is now used to extract beneficial elements, mainly small-scale extraction of vanadium pentoxide. Vanadium is an important rare metal that has been widely used in ferrous and non-ferrous alloys to improve its hardness, tensile strength, and fatigue resistance, and vanadium oxide is widely applied [17-19]. In China, apart from vanadium titano-magnetite, carbonaceous shale, also called stone coal, is another important vanadium-bearing resource due to the vast amount of deposits [20]. The gross reserve of vanadium in terms of $\mathrm{V}_{2} \mathrm{O}_{5}$ in stone coal accounts for more than $87 \%$ of the domestic reserve of vanadium [21]. Generally, most vanadium in stone coal exists in terms of isomorphism, where $\mathrm{V}^{3+}$ substitutes for $\mathrm{Al}^{3+}$ in the crystal lattice of aluminosilicates including muscovite, tourmaline, and garnet, because $\mathrm{V}^{3+}$ has a similar electronegativity and ionic radius to $\mathrm{Al}^{3+}[22,23]$. In addition, small amounts of vanadium in the form of adsorbed state adsorb on the surface of clay minerals such as kaolinite [24]. After the extraction of vanadium, if research on stone coal after extracting vanadium continues, the utilization of stone coal resources will be fully, effectively, and reasonably developed. Due to the complex mineral composition of stone coal, in order to fully exploit and utilize abundant stone coal resources and guide the preparation of composite materials using stone coal as a raw material, it is necessary to thoroughly explore the mineralogical and thermal storage characteristics of stone coal.

In recent years, mineralogical characteristics have been used to study stone coal. Researchers have studied stone coal by various characterization methods so as to explore the nature of minerals, extract vanadium, and prepare materials. To explore the flotation technology of high-carbon stone coal bearing vanadium, Wang et al. [9] studied the mineralogical characteristics of stone coal by XRD, scanning electron microscope-energy dispersive spectrometer (SEM-EDS), and optical micrographs. To optimize the roasting method and conditions to improve the leaching efficiency of vanadium pentoxide $\left(\mathrm{V}_{2} \mathrm{O}_{5}\right)$, Zeng et al. [25] investigated the oxidizing roasting of stone coal in a laboratory fluidized bed reactor by means of X-ray fluorescence (XRF), SEM-EDS, and XRD. Furthermore, $\mathrm{Hu}$ et al. [26] explored the separation of $\mathrm{V}$ over Fe impurities from V-bearing shale using oxalic acid as an eco-friendly leachant by XRF, XRD, and SEM-EDS. Xie et al. [16] also explored activated carbon (AC), vanadium oxide $\left(\mathrm{V}_{2} \mathrm{O}_{5}\right)$, and $\mathrm{V}_{2} \mathrm{O}_{5} / \mathrm{AC}$ photocatalyst prepared by in situ utilization of stone coal ore by XRD, XRF, Fourier transformation infrared spectroscopy (FTIR), SEM, Brunauer-Emmett-Teller (BET), and thermogravimetric-differential thermal analyzer (TG-DTA). In addition, Gao et al. [27-30] explored the nature of minerals by calculating surface broken bonds combined with mineralogical features. Therefore, the mineralogical characteristics of stone coal can serve as a guide for subsequent work on stone coal. However, the use of stone coal as a raw material for the preparation of phase change composites also requires research on its thermal storage characteristics.

As a natural mineral, stone coal has the potential to be used to prepare composite thermal storage materials. However, few studied related to stone coal-based composite thermal storage materials have been reported. Some scholars have studied a composite of coal-series kaolin (coal gangue) and fatty acid as form-stable phase change material [31,32]. Stone coal with a lower carbonization degree has similar properties to coal gangue [33], so it is meaningful to study the thermal storage characteristics of stone coal. In this paper, mineralogical and thermal storage studies of stone coal were conducted 
with the purpose of preparing thermal storage materials by the comparison of the mineralogical and thermal storage characteristics of two types of stone coal.

\section{Materials and Methods}

\subsection{Materials}

Two kinds of stone coal (weathered stone coal and high-carbon stone coal) were sampled from the pond of a stone coal mine in Henan, China. After being transported to the laboratory, these stone coal samples were air-dried, ground to pass through a $0.074 \mathrm{~mm}$ metal sieve, homogenized, and stored in polypropylene plastic sample bags. The weathered stone coal and high-carbon stone coal were labeled as $\mathrm{SC}_{\mathrm{wt}}$ and $\mathrm{SC}_{\mathrm{hc}}$, respectively.

\subsection{Preparation of the $S A / S C$ Composites}

The SA/SC composites were synthesized via vacuum impregnation [34,35], and stearic acid $\left(\mathrm{CH}_{3}\left(\mathrm{CH}_{2}\right)_{16} \mathrm{COOH}, \mathrm{SA}\right)$ with a phase change temperature range of $56-69.9^{\circ} \mathrm{C}$ was supplied by Tianjin Hengxing Chemical Reagent Co., Ltd., Tianjin, China. The following is the fabrication process: $10 \mathrm{~g}$ SA (an excess) and $5.0 \mathrm{~g}$ SC were put into an Erlenmeyer flask, which was concatenated to a suction pump by using a unit for preventing backward suction. A vacuum was created in the Erlenmeyer flask at $-0.1 \mathrm{MPa}$ for $5 \mathrm{~min}$, and then its temperature was maintained at $95{ }^{\circ} \mathrm{C}$ for $30 \mathrm{~min}$ via a constant temperature bath. The vacuum was released and the flask heated to $80{ }^{\circ} \mathrm{C}$ for $5 \mathrm{~min}$ in an ultrasonic bath before cooling to room temperature. The resulting mixture was filtered at $80{ }^{\circ} \mathrm{C}$ to produce the final stearic acid/stone coal (SA/SC) composites. The composites were labeled as SA/SC $\mathrm{wt}_{\mathrm{w}}$ and $\mathrm{SA} / \mathrm{SC}_{\mathrm{hc}}$, respectively.

\subsection{Characterization}

The elemental composition of raw stone coals $\left(\mathrm{SC}_{\mathrm{wt}}\right.$ and $\mathrm{SC}_{\mathrm{hc}}$ ) was determined by $\mathrm{X}$-ray fluorescence (XRF, PANalytical B.V., Almelo, The Netherlands) using radiation at an acceleration voltage of $60 \mathrm{kV}$ and a current of $100 \mathrm{~mA}$. X-ray diffraction (XRD, Bruker Corporation, Billerica, MA, USA) was carried out using a D8 ADVANCE analyzer $(\mathrm{Cu}-\mathrm{K} \alpha)$ under the following conditions: voltage $40 \mathrm{kV}$, current $250 \mathrm{~mA}$, scan range from 3 to $80^{\circ}$, and step size of $0.5^{\circ}$. The crystalline phases of samples were identified using the software Jade 6.5 compiled by Materials Data Inc. (MDI, California, CA, USA). The stone coal was embedded in the epoxy resin and polished for the petrography analysis, and the photomicrographs were then obtained using an Axiovert 200 mat photomicroscope; furthermore, a scanning electron microscope (SEM)-energy dispersive spectrometer (EDS, JEOL, Tokyo, Japan) was used on the polished samples under the backscattered electron (BSE, JEOL, Tokyo, Japan) mode by JEOL JSM-6490LV. The samples were pressed onto a conductive adhesive tab mounted on a copper stub and coated with gold before the test, and the corresponding microstructures were investigated using a Zeiss Sigma 500 scanning electron microscope (SEM, Carl Zeiss AG, Oberkochen, Germany) operated at an accelerating voltage. Fourier transformation infrared spectroscopy (FTIR, SHIMADZU, Japan) spectra were recorded using an IR tracer-100AH FTIR spectrometer in the range of $4000 \sim 400 \mathrm{~cm}^{-1}$ at $20 \mathrm{kV}$. A thermogravimetric analysis (TGA, HENVEN HCT-3, Beijing Henven Scientific Instrument Factory, Beijing, China) was conducted at a heating rate of $15{ }^{\circ} \mathrm{C} \cdot \mathrm{min}^{-1}$ up to $1100{ }^{\circ} \mathrm{C}$ in oxygen atmosphere. The thermal conductivity of two samples pressed into tablets was recorded using a DRX-I-300. Before testing the samples, the samples had to be to be prepared into wafers with a thickness of about $1 \mathrm{~mm}$ and a diameter of $12 \mathrm{~mm}$. Differential scanning calorimetry (DSC) analysis of stearic acid and the composites was performed using a TA instruments DSC Q10 (V9.9 Build 303, New Castle, DE, USA) at a heating rate of $5^{\circ} \mathrm{C} / \mathrm{min}$ under a constant stream of argon at atmospheric pressure. Liquid nitrogen was used to cool the sample during the freezing period. 


\section{Results}

\subsection{Elemental Composition}

The main components of $\mathrm{SC}_{\mathrm{wt}}$ were $\mathrm{Si}, \mathrm{Al}$, and $\mathrm{Fe}$, while the content of $\mathrm{Ca}, \mathrm{K}, \mathrm{Ba}, \mathrm{V}$, and $\mathrm{P}$ was less (Table 1). The main components of $\mathrm{SC}_{\mathrm{hc}}$ were $\mathrm{Si}, \mathrm{Al}$, and $\mathrm{Fe}$, while the content of $\mathrm{Cr}, \mathrm{K}, \mathrm{Ba}, \mathrm{V}$, and $\mathrm{P}$ was less. The content of $\mathrm{V}$ was $8182.42 \mathrm{ppm}$ and $5479.98 \mathrm{ppm}$ for $\mathrm{SC}_{\mathrm{wt}}$ and $\mathrm{SC}_{\mathrm{hc}}$, respectively, indicating that the $\mathrm{SC}_{\mathrm{wt}}$ includes more vanadium. Other valuable elements, such as $\mathrm{Cu}, \mathrm{Zn}, \mathrm{Ni}$, and $\mathrm{Mo}$, are low in the mineral composition, making little sense if recycled.

Table 1. X-ray fluorescence (XRF) results of samples (ppm).

\begin{tabular}{cccccccccc}
\hline & $\mathbf{N a}$ & $\mathbf{M g}$ & $\mathbf{A l}$ & $\mathbf{S i}$ & $\mathbf{P}$ & $\mathbf{S O}_{3}$ & $\mathbf{C l}$ & $\mathbf{K}$ & $\mathbf{C a}$ \\
\hline $\mathrm{SC}_{\mathrm{wt}}$ & 764.19 & 5646 & $41,876.47$ & $308,186.67$ & 4366.20 & 18,700 & 18,000 & 8546.81 & $20,642.86$ \\
$\mathrm{SC}_{\mathrm{hc}}$ & 487.45 & 2588.4 & $45,837.53$ & $243,231.8$ & 2841.96 & 567 & 0 & $10,652.81$ & 2068.57 \\
\hline & $\mathbf{T i}$ & $\mathbf{V}$ & $\mathbf{C r}$ & $\mathbf{C u}$ & $\mathbf{Z n}$ & $\mathbf{A s}$ & $\mathbf{S e}$ & $\mathbf{R b}$ & $\mathbf{S r}$ \\
\hline $\mathrm{SC}_{\mathrm{wt}}$ & 1362 & 8182.42 & 841.58 & 616 & 1348.15 & 143.94 & 35.59 & 27.43 & 725.15 \\
$\mathrm{SC}_{\mathrm{hc}}$ & 1468.8 & 5479.98 & 9713.74 & 393.6 & 95.49 & 237.12 & 0 & 33.83 & 445.08 \\
\hline & $\mathbf{Y}$ & $\mathbf{Z r}$ & $\mathbf{M o}$ & $\mathbf{B a}$ & $\mathbf{P b}$ & $\mathbf{C o}$ & $\mathbf{M n}$ & $\mathbf{F e}$ & $\mathbf{N i}$ \\
\hline $\mathrm{SC}_{\mathrm{wt}}$ & 126.02 & 63.63 & 46.67 & $30,623.53$ & 176.37 & 15.73 & 123.94 & 38,745 & 330.4 \\
$\mathrm{SC}_{\mathrm{hc}}$ & 57.5 & 46.61 & 42.67 & $20,451.50$ & 41.77 & 11.8 & 179.72 & $21,886.9$ & 815.77 \\
\hline
\end{tabular}

\subsection{Mineralogical Composition}

Figure 1 shows the $\mathrm{XRD}$ patterns of the $\mathrm{SC}_{\mathrm{wt}}$ and $\mathrm{SC}_{\mathrm{hc}}$, indicating the respective phase composition such as quartz, kaolinite, roscoelite, and goethite [36]. It can clearly be seen from the XRD curve that the phase of the two stone coals is similar. The major phase of $\mathrm{SC}_{\mathrm{wt}}$ and $\mathrm{SC}_{\mathrm{hc}}$ was quartz. Combined with the results of the $\mathrm{XRF}, \mathrm{Fe}, \mathrm{Ca}$, and $\mathrm{Si}$ in $\mathrm{SC}_{\mathrm{wt}}$ were slightly more than in $\mathrm{SC}_{\mathrm{hc}}$. The content of $\mathrm{V}$ in $\mathrm{SC}_{\mathrm{wt}}$ is slightly greater than in $\mathrm{SC}_{\mathrm{hc}}$, whereas the content of $\mathrm{Al}$ and $\mathrm{K}$ in $\mathrm{SC}_{\mathrm{wt}}$ is slightly lower than in $\mathrm{SC}_{\mathrm{hc}}$. This may be because the goethite in $\mathrm{SC}_{\mathrm{wt}}$ contains a small amount of vanadium [37]. Vanadium seems to be affiliated mainly with roscoelite.
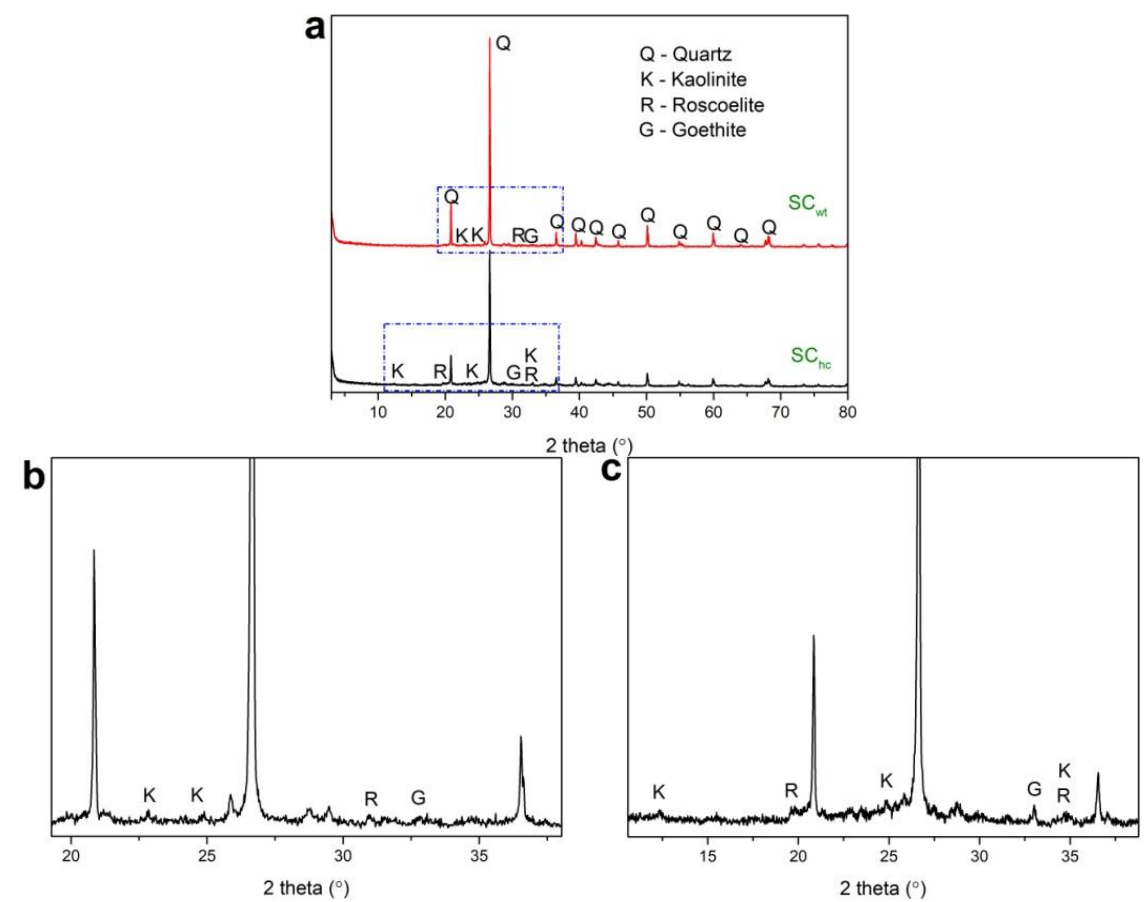

Figure 1. XRD patterns of the stone coal (a), partial enlargement of the XRD of $\operatorname{SC}_{w t}(\mathbf{b})$ and partial enlargement of the XRD of $\mathrm{SC}_{\mathrm{hc}}(\mathrm{c})$. 


\subsection{FTIR Analysis}

The FTIR spectra of samples are shown in Figure 2. The absorption at $3442 \mathrm{~cm}^{-1}$ and $2359 \mathrm{~cm}^{-1}$ in all samples was attributed to loosely bound water $(v(\mathrm{H}-\mathrm{O}-\mathrm{H}))$ [38] and $\mathrm{Al}-\mathrm{OH}$ [39], and the band at $2924 \mathrm{~cm}^{-1}$ in all samples was crystalline water (free water) [39]. The absorption bands at $1730 \mathrm{~cm}^{-1}$ and $1647 \mathrm{~cm}^{-1}$ were bending vibrations from adsorbed water in roscoelite [39]. The bands at $1456 \mathrm{~cm}^{-1}$ in all samples were attributed to stretching vibrations from $\mathrm{CO}_{3}{ }^{2-}$ in carbonate impurities $[39,40]$. The band at $1377 \mathrm{~cm}^{-1}$ in all samples was attributed to symmetric stretching vibrations from adsorbed $\mathrm{CO}_{2}$ [41]. The bands at $1094 \mathrm{~cm}^{-1}$ in $\mathrm{SC}_{\mathrm{wt}}$ and $1089 \mathrm{~cm}^{-1}$ in $\mathrm{SC}_{\mathrm{hc}}$ were attributed to antisymmetric stretching vibrations from Si-O-Si in roscoelite and quartz [42]. The bands at $692 \mathrm{~cm}^{-1}$ and $798 \mathrm{~cm}^{-1}$ in all samples were attributed to symmetric stretching vibrations from $\mathrm{Si}-\mathrm{O}-\mathrm{Si}$ in quartz [42]. The band at $515 \mathrm{~cm}^{-1}$ in all samples was attributed to $\mathrm{Si}-\mathrm{O}-\mathrm{Al}^{\mathrm{VI}}$ bending [43]. The bands at $469 \mathrm{~cm}^{-1}$ in all samples were attributed to $\mathrm{Si}-\mathrm{O}$ and $\mathrm{Si}-\mathrm{O}-\mathrm{Si}$ bending [39].

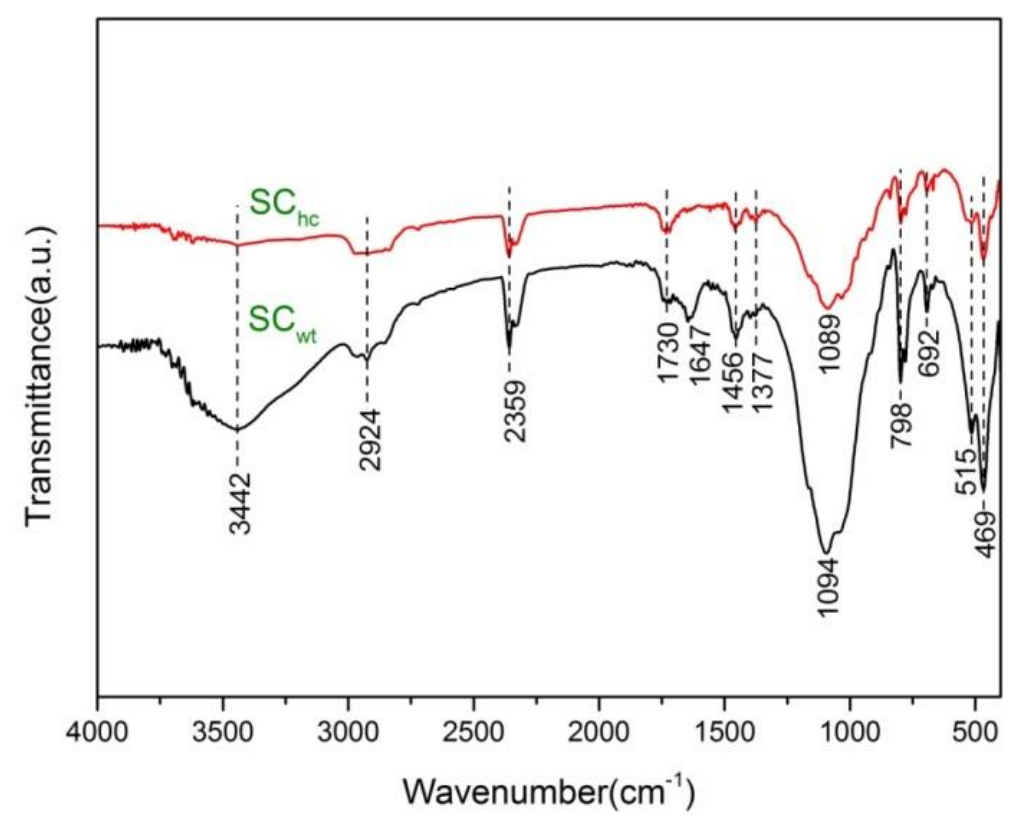

Figure 2. Fourier transformation infrared spectroscopy (FTIR) spectra of stone coal (SC).

\subsection{TG-DTA Analysis}

The TG and DTA curves of $\mathrm{SC}_{\mathrm{wt}}$ under the flow of $\mathrm{O}_{2}$ are shown in Figure 3a. According to the TG curve, free water was released in the temperature range of $15-100{ }^{\circ} \mathrm{C}$ with a mass loss of $1.28 \%$. Dehydration of lattice water occurred in the range of $100-689^{\circ} \mathrm{C}$ with a mass loss of $4.82 \%$. From $689^{\circ} \mathrm{C}$ to $879{ }^{\circ} \mathrm{C}$, the weight loss was relatively stable, with a mass loss of $0.23 \%$. From $879{ }^{\circ} \mathrm{C}$ to $1140{ }^{\circ} \mathrm{C}$, the weight loss maintained a rising trend with a mass loss of $1.66 \%$ due to the removal of the structural hydroxyl groups from aluminosilicate minerals [41]. The TG curve of $\mathrm{SC}_{\mathrm{wt}}$ has no obvious weightlessness step, while the corresponding DTA curve is a smooth curve without an obvious endothermic peak. Figure $3 \mathrm{~b}$ shows the TG and DTA curves of $\mathrm{SC}_{\mathrm{hc}}$ under the flow of $\mathrm{O}_{2}$. According to the TG curve, free water was released in the temperature range of $15-100{ }^{\circ} \mathrm{C}$ with a mass loss of $2.74 \%$. The lattice water and structural hydroxyls (part) were released in $100-436{ }^{\circ} \mathrm{C}$ with a mass loss of $4.00 \%$. From 436 to $600{ }^{\circ} \mathrm{C}$, the weight loss increased seriously, with a mass loss of $22.44 \%$ due to the carbon oxidized and the dehydration of lattice water [44]. From 600 to $1130{ }^{\circ} \mathrm{C}$, the weight loss maintained the rising trend, with a mass loss of $3.13 \%$ due to the removal of the structural hydroxyl groups from aluminosilicate minerals [41]. The TG curve of $\mathrm{SC}_{\mathrm{hc}}$ has an obvious weightlessness step, and in the DTA curve, an endothermic peak above $500{ }^{\circ} \mathrm{C}$ suggests that the endothermic enthalpies 
of $\mathrm{SC}_{\mathrm{hc}}$ increased. There were no obvious chemical reactions in $\mathrm{SC}_{\mathrm{wt}}$ under $\mathrm{O}_{2}$ atmosphere at room temperature to $1140{ }^{\circ} \mathrm{C}$. This indicates that the $\mathrm{SC}_{\mathrm{wt}}$ had good thermal stability.
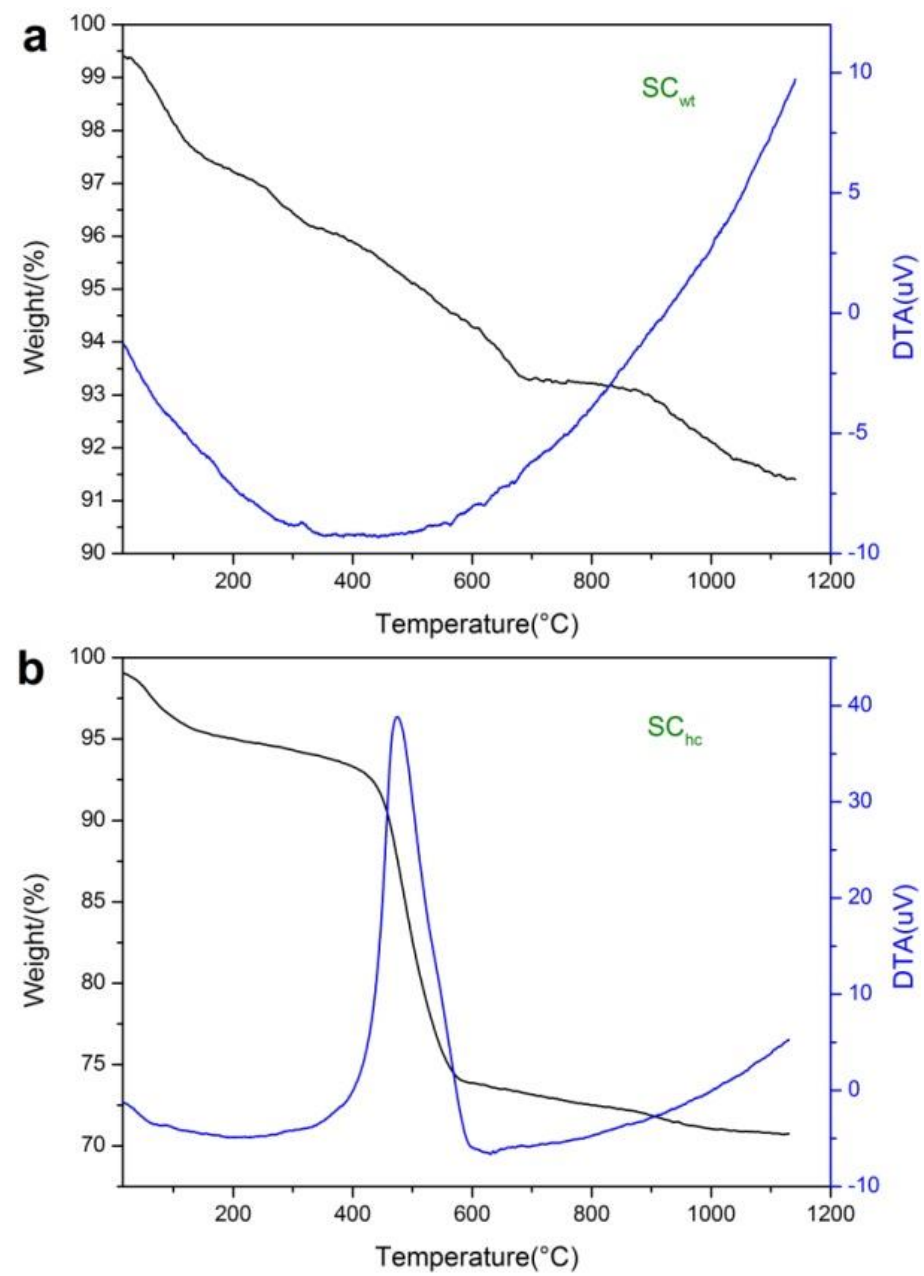

Figure 3. Thermogravimetric analysis (TGA) (weight loss curve and differential thermal analysis (DTA) curves of (a) $\mathrm{SC}_{\mathrm{wt}}$ and (b) $\mathrm{SC}_{\mathrm{hc}}$ in oxygen atmosphere.

\subsection{Reflected Light Microscopy Images Analysis}

The study of petrography is useful for the identification of rocks, minerals, and ores $[38,45]$. The reflected light microscopy images demonstrated that four types of mineral phases were easily distinguished in two samples (Figure 4). The optical characteristic of roscoelite is that the $\perp$ Bxa interferogram can be seen on the (001) plane, and the irregular roscoelite particles were surrounded by quartz. According to the optical characteristic of roscoelite, the dark roscoelite contains Fe impurities or carbonaceous impurities (Figure $4 \mathrm{~b}, \mathrm{c}$ ). Goethite was distributed in kaolinite in a wide range of sizes. Kaolinite is mainly distributed along the bedding planes and, to a lesser extent, occurs as disseminated fine particles (Figure 4a,d) [8]. Therefore, the mineralography compositions of these samples were quartz, kaolinite, goethite, and roscoelite. However, the amount and size of roscoelite in $\mathrm{SC}_{\mathrm{wt}}$ was slightly larger than in $\mathrm{SC}_{\mathrm{hc}}$, and the brownish-yellow area was also significantly larger than in $\mathrm{SC}_{\mathrm{hc}}$. These results were in accord with the XRF and XRD results. 

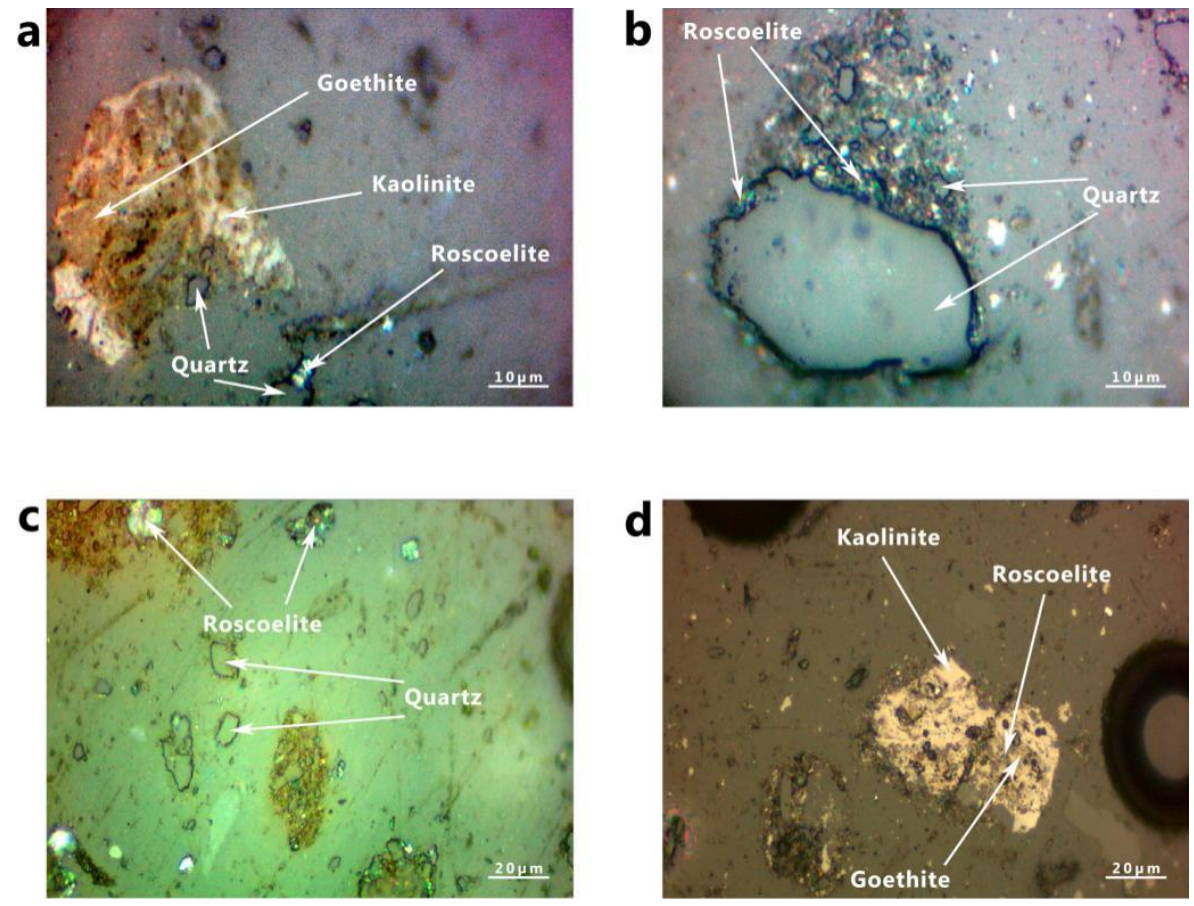

Figure 4. Reflected light microscopy images of $\mathrm{SC}_{\mathrm{wt}}(\mathbf{a}, \mathbf{b})$ and $\mathrm{SC}_{\mathrm{hc}}(\mathbf{c}, \mathbf{d})$.

\subsection{SEM-EDS Analysis}

The SEM-EDS analysis of the stone coal samples is presented in Figure 5, and atomic composition contrasts are also identified. Figure $5 \mathrm{a}, \mathrm{c}$ shows that the particles were well separated from each other and that the shape of these particles is irregular. The stone coal samples presented flaky and pellet structures; the size of the flaky structures was 1-2 $\mu \mathrm{m}$, while the size of the pellet structures was $0.1-1 \mu \mathrm{m}$. It is revealed that flaky structures were interspersed throughout the pellet structures. According to the EDS results (Figure $5 b, d$ ), the $V$ element emerged in both $\mathrm{SC}_{\mathrm{wt}}$ and $\mathrm{SC}_{\mathrm{hc}}$. These results are in accord with the reflected light microscopy images and XRF results of the stone coal.

Secondary electron (SE) images and EDS elemental maps of $\mathrm{SC}_{\mathrm{wt}}$ and $\mathrm{SC}_{\mathrm{hc}}$ are shown in Figures 6 and 7 , respectively. These indicate that $\mathrm{Si}$ (Figures $6 \mathrm{~b}$ and $7 \mathrm{~b}$ ), $\mathrm{O}$ (Figures $6 \mathrm{c}$ and $7 \mathrm{c}$ ), and $\mathrm{Al}$ (Figures $6 \mathrm{~d}$ and $7 \mathrm{~d}$ ) emerged in the concentrated distribution, and Fe (Figures 6e and 7e) and V (Figures $6 \mathrm{f}$ and 7f) presented the uniform distribution. Si and $\mathrm{O}$ mainly originated from quartz, and $\mathrm{Al}$ was from aluminosilicate (kaolinite and roscoelite). Fe and $\mathrm{V}$ were geared to goethite and roscoelite, respectively. The elemental mapping diagrams of the two stone coal samples are similar, indicating that their elemental composition and phase distributions are similar. The contents of vanadium minerals are usually very low and are commonly detrital materials of terrigenous origin and, to a lesser extent, from epigenetic igneous hydrothermal solutions [15]. Vanadium and roscoelite have a relatively obvious synchronous distribution. Most of the vanadium in stone coal occurs in ground roscoelite. The presence of $\mathrm{V}$ leads to the possibility of having roscoelite [7]. This suggests that roscoelite was formed by a complex reaction involving a change in the oxidation-reduction potential of the groundwater and the presence in the sandstone of sensitive associations of minerals containing vanadium-rich iron and titanium oxides. The reduction spots formed by diffusion as part of the same process [46]. The occurrence of roscoelite in depositional environment indicates input from hydrothermal fluids [15]. The roscoelite is of authigenic origin and was probably derived from the interaction between $\mathrm{V}$ derived from penetrating V-rich solutions and kaolinite already present in the coal during an early stage of the diagenetic process [47]. The sediment-source region for the coal was mainly due to Mesozoic intermediate-felsic volcanic rocks [8]. These results were in accord with the $\mathrm{XRF}$ results of the stone coal. 

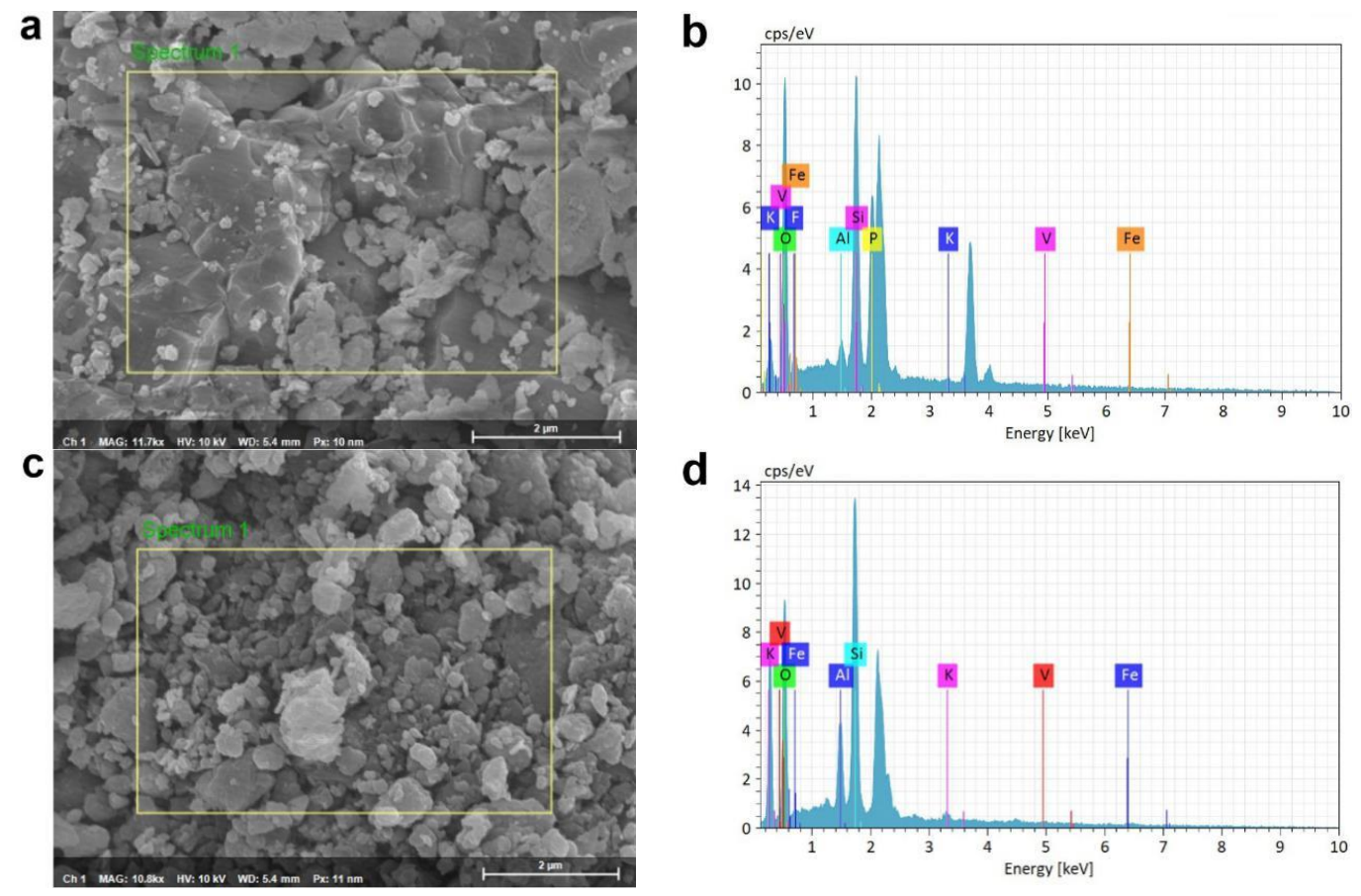

Figure 5. Scanning electron microscope and energy dispersive $\mathrm{X}$-ray spectroscopy of $\mathrm{SC}_{\mathrm{wt}}(\mathbf{a}, \mathbf{b})$ and $\mathrm{SC}_{\mathrm{hc}}(\mathbf{c}, \mathbf{d})$.
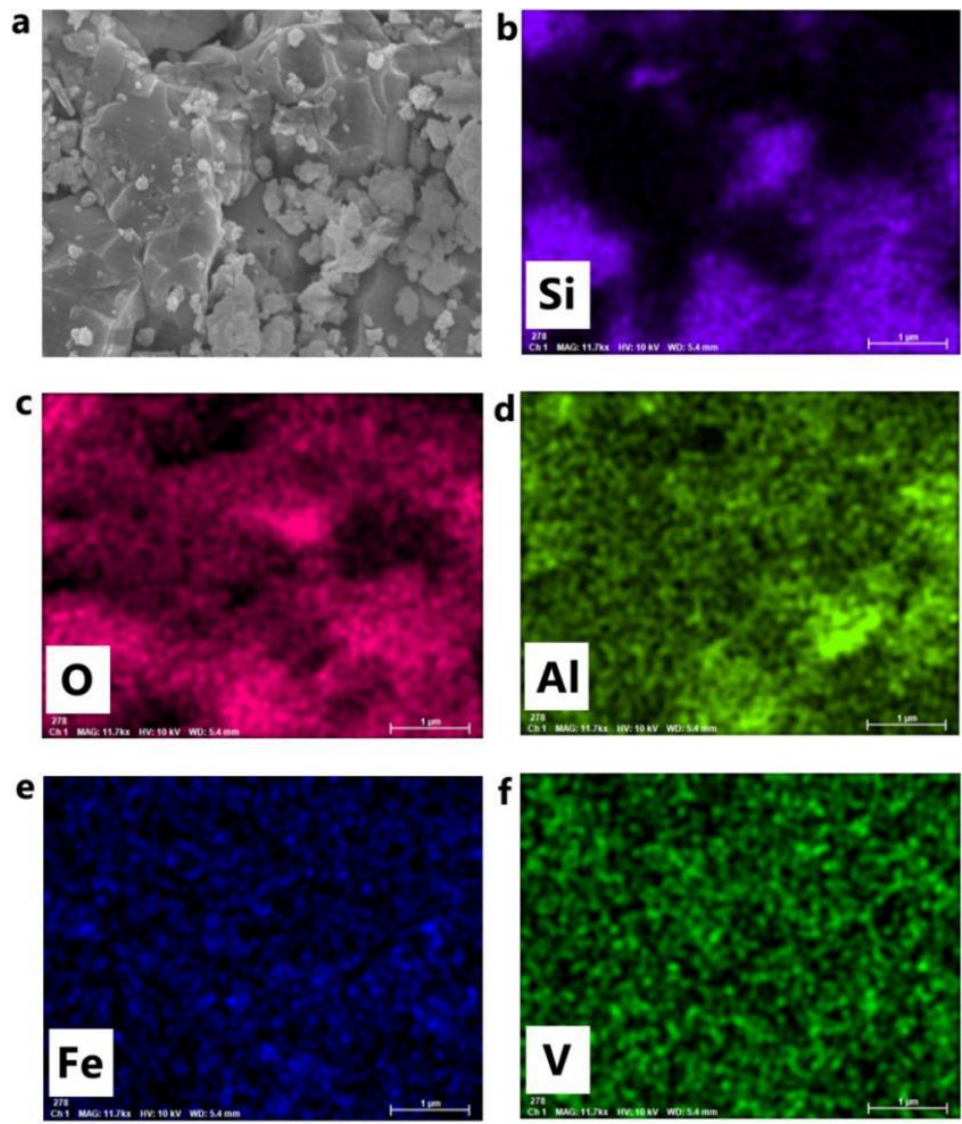

Figure 6. Secondary electron (SE) image and energy dispersive X-ray spectroscopic (EDS) elemental

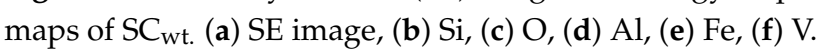



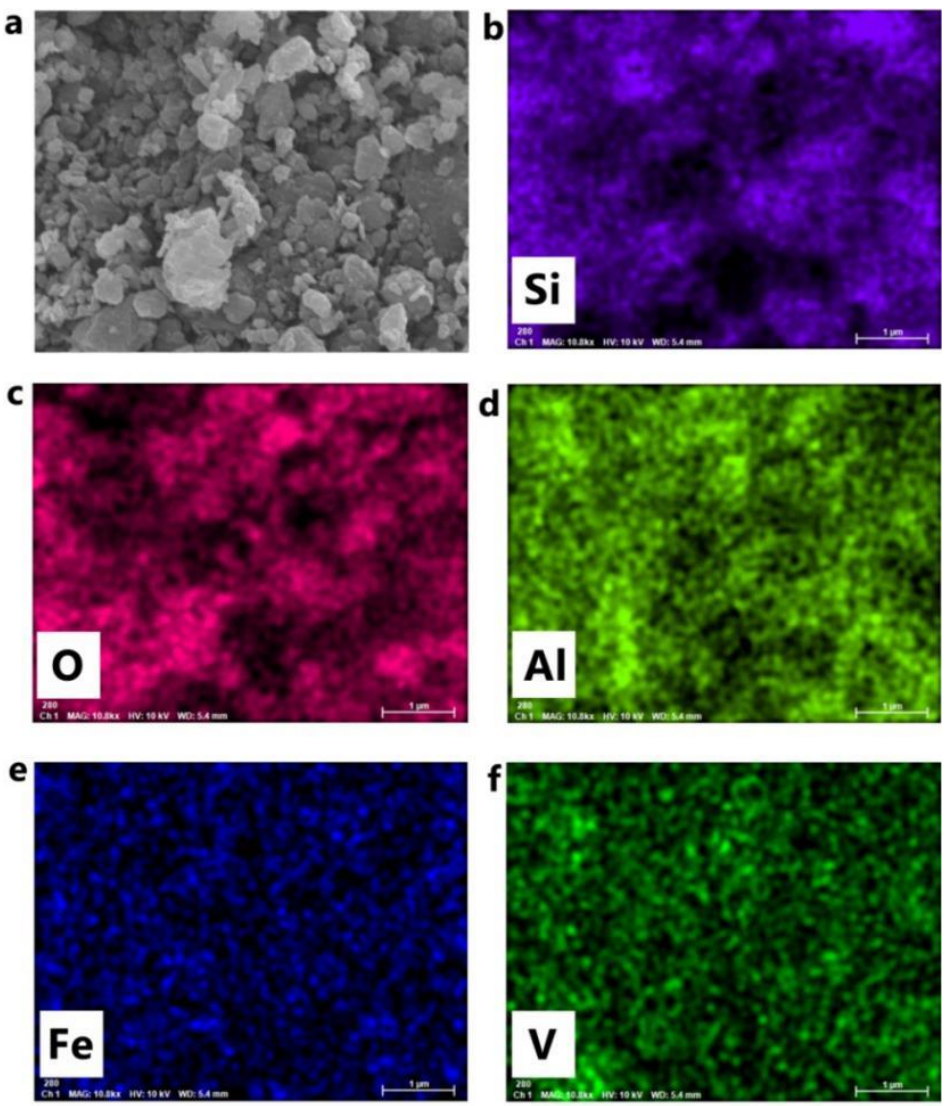

Figure 7. Secondary electron (SE) image and energy dispersive $X$-ray spectroscopic (EDS) elemental maps of $\mathrm{SC}_{\mathrm{hc}}$. (a) SE image, (b) Si, (c) $\mathrm{O}$, (d) Al, (e) Fe, (f) V.

The EDS of the SC samples under the backscattered electron (BSE) mode is presented in Figure 8, and atomic composition contrasts (Z-contrast) are also identified. The original EDS data are provided in the Supplementary Materials. Four different contrasts can be seen in Figure 8a and are labeled as A1, A2, A3, and A4, respectively. According to the EDS results (Figure 8b), the A1, A2, A3, and A3 were quartz (dark-gray large grain), kaolinite (dark-gray small flake), roscoelite (light gray), and goethite (bright gray), respectively, in the $\mathrm{SC}_{\mathrm{wt}}$. This may be because the primary particles of $\mathrm{SC}_{\mathrm{hc}}$ are too small, and the color between the phases is not much different. But relying on the EDS analysis, quartz, kaolinite, and roscoelite were also discovered in the $\mathrm{SC}_{\mathrm{hc}}$ (Figure $8 \mathrm{c}, \mathrm{d}$ ) and labeled as $\mathrm{C} 1, \mathrm{C} 2$, and C3, respectively. Moreover, quartz, kaolinite, and goethite emerged in Figure 8e, and the corresponding EDS is presented in Figure 8f (E1, E2, and E3). These results were in accord with the reflected light microscopy images and XRF results of the stone coal. In addition, relatively little roscoelite, kaolinite, and goethite were detected according to the BSE and EDS. This is also the reason why the characteristic peaks of kaolinite, goethite, and roscoelite are not obvious in the XRD results. Nevertheless, the optical properties of the minerals in the reflected light microscopy and the results of the EDS data and their elemental composition imply the possible presence of kaolinite, goethite, and roscoelite. 

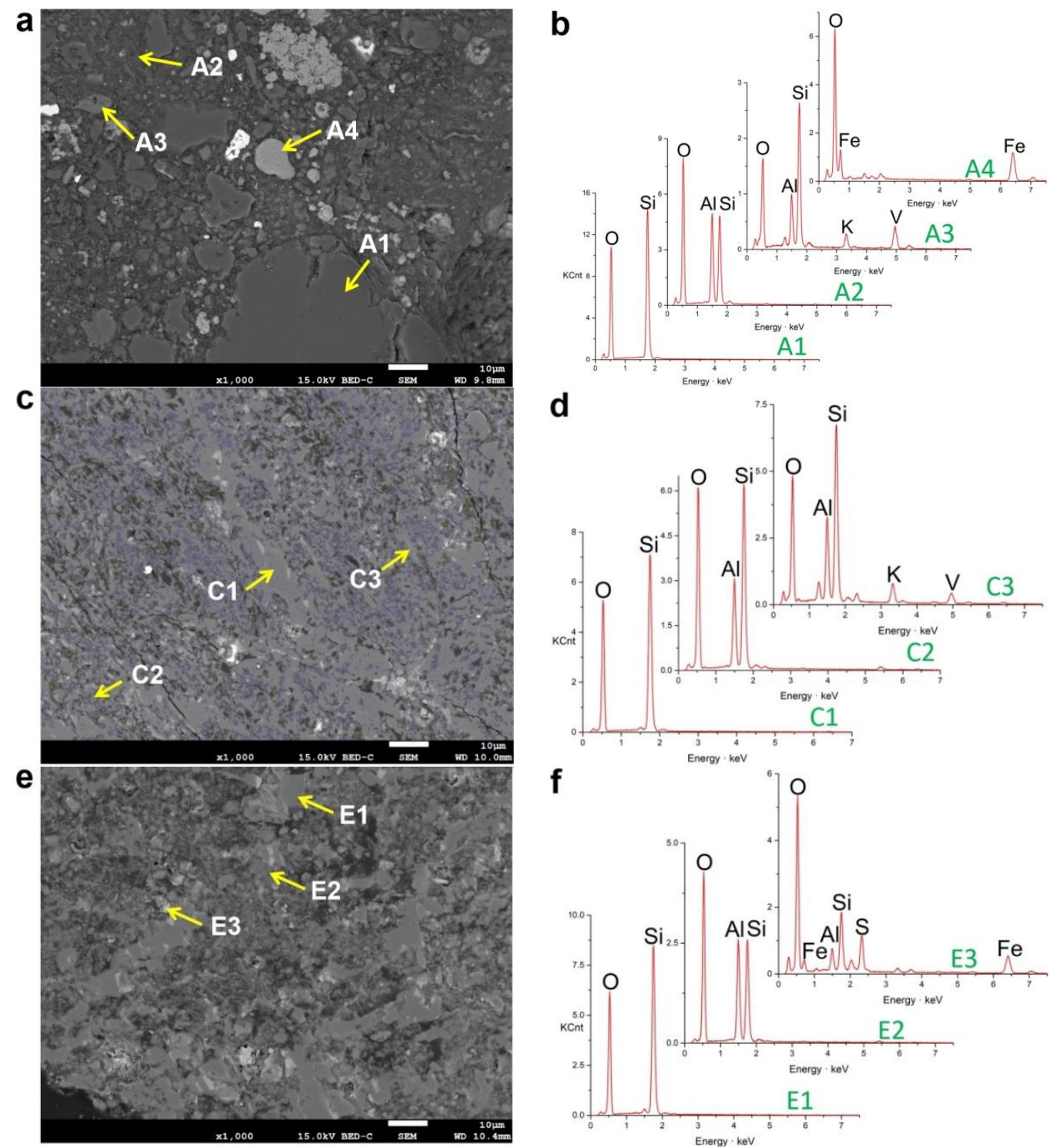

Figure 8. Backscattered electron $\mathrm{z}$-contrast (BSE-Z) images and energy dispersive $X$-ray spectroscopy (EDS) of quartz, kaolinite, goethite, and roscoelite in $\mathrm{SC}_{\mathrm{wt}}(\mathbf{a}, \mathbf{b})$ and $\mathrm{SC}_{\mathrm{hc}}(\mathbf{c}-\mathbf{f})$. (A1: quartz; $\mathrm{A} 2$ : kaolinite; A3: roscoelite; A4: goethite; C1: quartz; C2: kaolinite; C3: roscoelite; E1: quartz; E2: kaolinite; E3: goethite).

\subsection{The Thermal Conductivity of Stone Coal}

Thermal conductivity is a fundamental factor for composite thermal storage material. The thermal conductivity of $\mathrm{SC}_{\mathrm{wt}}$ is $0.19 \mathrm{~W} \mathrm{~m}^{-1} \mathrm{k}^{-1}$, while the thermal conductivity of $\mathrm{SC}_{\mathrm{hc}}$ is $0.24 \mathrm{~W} \mathrm{~m}^{-1} \mathrm{k}^{-1}$. The thermal conductivity of $\mathrm{SC}_{\mathrm{hc}}$ is slightly greater due to the sample having a high carbon content. It indicates that the $\mathrm{SC}_{\mathrm{hc}}$ is more suitable for use as a composite thermal storage material. According to the lattice theory, it is known that stone coal contains a large amount of silicate, and the $\mathrm{Si}-\mathrm{O}$ bond is the most powerful in the composition, so the crystal vibration of the grid is the most efficient in this direction. According to the composition analysis of stone coal, the content of stone coal is complicated and the $\mathrm{Si}-\mathrm{O}$ bond in the unit cell increases, which will increase the vibration coupling between the cells, and the phonon collision will increase, thus improving the thermal resistance. According to the composition analysis, the metal ion composition in stone coal is also very different. However, the metal ion generally does not participate in the phonon conduction, but the vibration of the $\mathrm{Si}-\mathrm{O}$ bond skeleton also partially excites the metal ion vibration, which also increases the difficulty of 
phonon propagation through the $\mathrm{Si}-\mathrm{O}$ skeleton, thereby reducing the thermal conductivities of stone coal [48]. The aforementioned results also provide the way for enhancing the thermal conductivity of stone coal, such as adding the carbon materials.

\subsection{Thermal Stability and Loading Capacity}

As shown in Figure $9 \mathrm{a}$, the curves of $\mathrm{SC}_{\mathrm{wt}}$ and $\mathrm{SC}_{\mathrm{hc}}$ under $\mathrm{N}_{2}$ are similar to those under $\mathrm{O}_{2}$, but are not as weightless as under $\mathrm{O}_{2}$. This was due to the release of free water and dehydration of lattice water, not an oxidizing reaction (Figure $9 b$ ). Only one single decomposition process existed in the tested temperature range of $\mathrm{SA} / \mathrm{SC}_{\mathrm{wt}}$, which was due to the degradation of $\mathrm{SA}$. The TG curve of SA/SC $\mathrm{hc}_{\mathrm{hc}}$ has two obvious weightlessness steps. An endothermic peak above $200{ }^{\circ} \mathrm{C}$ suggested decomposition of pure SA, and another endothermic peak in the curve of $\mathrm{SA} / \mathrm{SC}_{\mathrm{hc}}$ above $500^{\circ} \mathrm{C}$ was due to the dehydration of lattice water. As can be seen in Figure 9a, the maximum mass fractions of $\mathrm{SA}$ in SA/SC $\mathrm{St}_{\mathrm{wt}}$ and $\mathrm{SA} / \mathrm{SC}_{\mathrm{hc}}$ were $16.63 \%$ and $17.40 \%$, respectively. Thus, the loading capacity of $\mathrm{SC}_{\mathrm{hc}}$ for phase change materials is higher than that of $\mathrm{SC}_{\mathrm{wt}}$. The complete decomposition temperatures $\left(\mathrm{T}_{\max }\right)$ for $\mathrm{SA} / \mathrm{SC}_{\mathrm{wt}}$ and $\mathrm{SA} / \mathrm{SC}_{\mathrm{hc}}$ were in the range of $320-340^{\circ} \mathrm{C}$, indicating that the stone coal-based composite phase change materials (PCMs) had good thermal stability under $30{ }^{\circ} \mathrm{C}$. Moreover, the TG curves and DTA curves of $\mathrm{SCwt}, \mathrm{SC}_{\mathrm{hc}}, \mathrm{SA} / \mathrm{SC}_{\mathrm{wt}}$, and $\mathrm{SA} / \mathrm{SC}_{\mathrm{hc}}$ under the flow of $\mathrm{N}_{2}$ are shown in Figure 9.
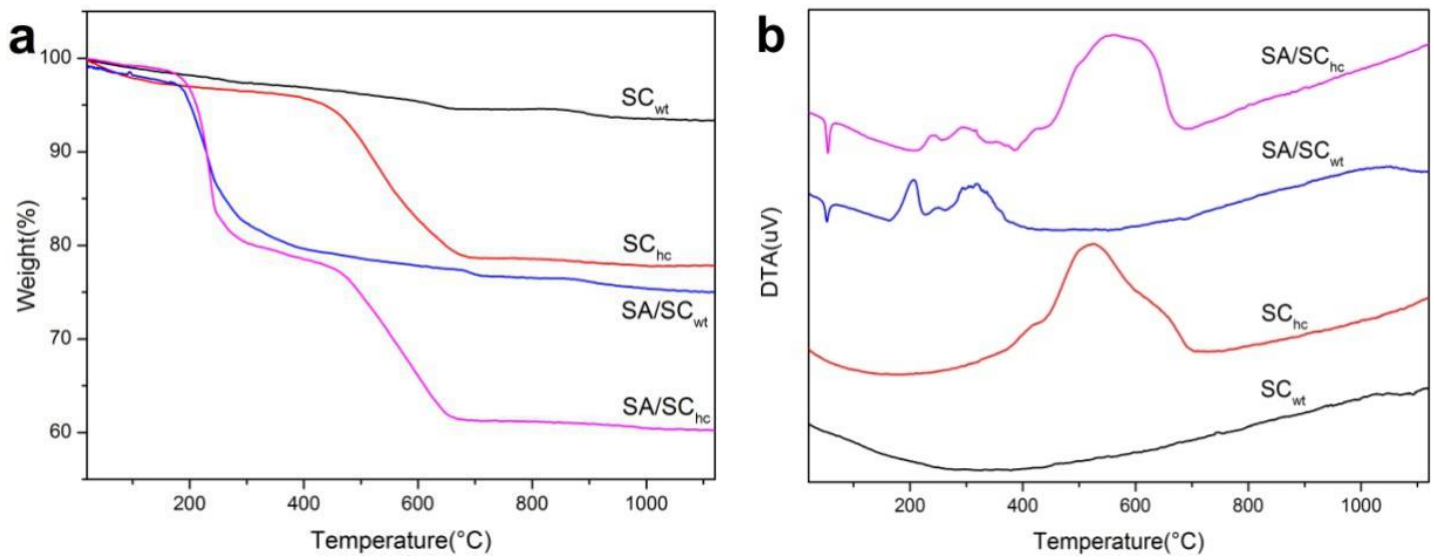

Figure 9. Thermogravimetric (TG) (a)-differential scanning calorimetry (DSC) (b) of $\mathrm{SC}_{\mathrm{wt}}, \mathrm{SC}_{\mathrm{hc}}$, $\mathrm{SA} / \mathrm{SC}_{\mathrm{wt}}$, and $\mathrm{SA} / \mathrm{SC}_{\mathrm{hc}}$.

\subsection{Thermal Storage Behavior of Composite Phase Change Materials}

It can be concluded that the thermal storage behavior of the composites was very close to that of the pure stearic acid (Figure 10), indicating no chemical reaction between stearic acid and stone coal during the preparation of the composites. The phase change properties were presented in Table 2 . The SA had a melting phase change temperature $\left(T_{\mathrm{m}}\right)$ of $52.91^{\circ} \mathrm{C}$ in the heating curve and a freezing phase change temperature $\left(T_{\mathrm{f}}\right)$ of $53.10^{\circ} \mathrm{C}$ in the cooling curve (Figure 10). DSC curves show that the heating curves of the two composites exhibit a peak; the phase change of $\mathrm{SA} / \mathrm{SC}_{\mathrm{wt}}$ was at $52.18^{\circ} \mathrm{C}$ (Figure 10), while the phase change of SA $/ \mathrm{SC}_{\mathrm{hc}}$ was at $52.77^{\circ} \mathrm{C}$ (Figure 10). Furthermore, two transitions (a liquid-solid phase transition of SA/SC $\mathrm{wt}_{\mathrm{wt}}$ at $50.15^{\circ} \mathrm{C}$ and a liquid-solid phase transition of $\mathrm{SA} / \mathrm{SC}_{\mathrm{hc}}$ at $\left.53.24{ }^{\circ} \mathrm{C}\right)$ appeared in the cooling curve. The latent heats of melting $\left(\Delta H_{m}\right)$ and freezing $\left(\Delta H_{f}\right)$, therefore, were calculated to be $190.2 \mathrm{~J} \mathrm{~g}^{-1}$ and $191.5 \mathrm{~J} \mathrm{~g}^{-1}$, respectively, for stearic acid. However, the latent heats of melting and freezing were $29.21 \mathrm{~J} \mathrm{~g}^{-1}$ and $30.55 \mathrm{~J} \mathrm{~g}^{-1}$ for SA/SC $\mathrm{Wt}_{\mathrm{wt}}$, and $33.02 \mathrm{~J} \mathrm{~g}^{-1}$ and $33.17 \mathrm{~J} \mathrm{~g}^{-1}$ for $\mathrm{SA} / \mathrm{SC}_{\mathrm{hc}}$, respectively. These values are lower than their theoretic values (Table 2). 
Table 2. Thermal properties of pure SA and SA/SC composites.

\begin{tabular}{|c|c|c|c|c|c|c|c|c|}
\hline Sample & Loadage $(\beta, \%)$ & $\begin{array}{c}\text { Melting } \\
\text { Temperature } \\
\left(T_{m},{ }^{\circ} \mathrm{C}\right)\end{array}$ & $\begin{array}{c}\text { Freezing } \\
\text { Temperature } \\
\left(T_{f},{ }^{\circ} \mathrm{C}\right)\end{array}$ & $\begin{array}{c}\text { Latent Heat of } \\
\text { Melting }\left(\Delta H_{m}, \mathrm{~J} \mathrm{~g}^{-1}\right)\end{array}$ & $\begin{array}{c}\text { Latent Heat of } \\
\text { Freezing }\left(\Delta H_{f}, \mathrm{~J} \mathrm{~g}^{-1}\right)\end{array}$ & $\begin{array}{c}\text { Theoretic } \\
\text { Values of } \Delta H_{m} \\
\left(\Delta H_{t h}, \mathrm{~J} \mathrm{~g}^{-1}\right)\end{array}$ & $\begin{array}{l}\text { Crystallinity } \\
\text { of SA }\left(F_{c}, \%\right)\end{array}$ & $\begin{array}{c}\text { Efficient Energy } \\
\text { per Unit Mass of } \\
\text { SA }\left(E_{\text {ef }}, J^{-1}\right)\end{array}$ \\
\hline SA & 100 & 52.91 & 53.10 & 190.2 & 191.5 & - & 100 & - \\
\hline $\mathrm{SA} / \mathrm{SC}_{\mathrm{wt}}$ & 16.63 & 52.18 & 50.15 & 29.21 & 30.55 & 31.63 & 92.35 & 175.64 \\
\hline $\mathrm{SA} / \mathrm{SC}_{\mathrm{hc}}$ & 17.40 & 52.81 & 53.24 & 33.02 & 33.17 & 33.09 & 99.78 & 189.78 \\
\hline
\end{tabular}




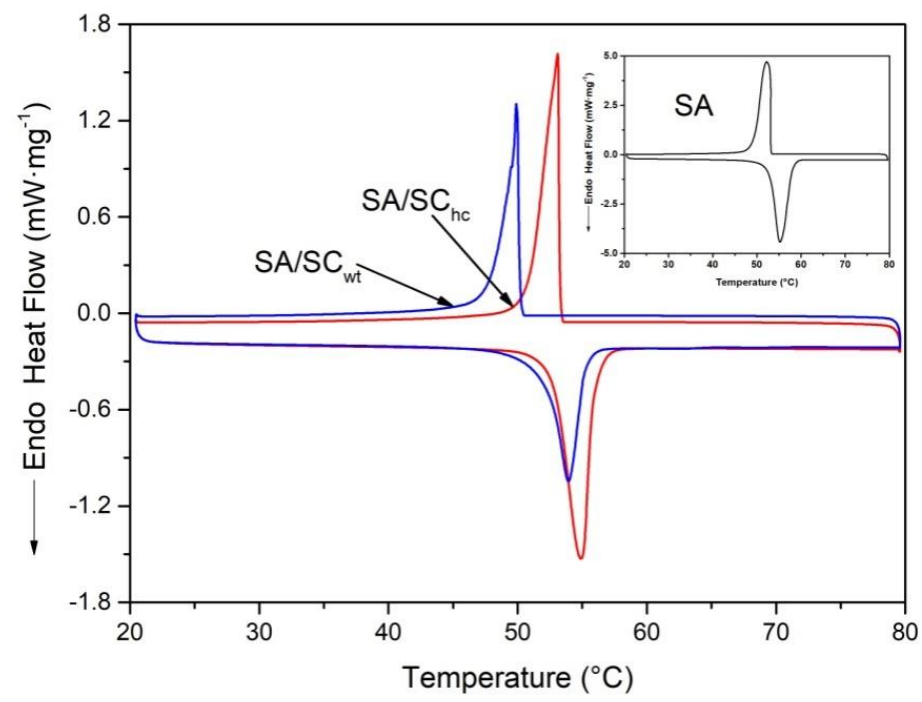

Figure 10. DSC curves of pure stearic acid (SA), $\mathrm{SA} / \mathrm{SC}_{\mathrm{wt}}$, and $\mathrm{SA} / \mathrm{SC}_{\mathrm{hc}}$.

The decrease in the latent heats of the composites is not only attributable to the lower fraction of stearic acid within the composites but could also be related to the crystallinity of the stearic acid in the composites. Crystallization of the stearic acid in the composites may be inhibited by interactions between the stearic acid and the substrate, which would also reduce the latent heats of the composites. The crystallinity of stearic acid $\left(F_{c}\right)$ and efficient energy $\left(E_{e f}\right)$ in the composite were calculated by [49-53]:

$$
\begin{gathered}
F_{c}=\frac{\Delta H_{\text {composite }}}{\Delta H_{P C M} \beta} \times 100 \%, \\
E_{e f}=\Delta H_{P C M} \times F_{c},
\end{gathered}
$$

where $\Delta H_{\text {composite }}$ and $\Delta H_{P C M}$ are the latent heats of the composites and pure stearic acid, respectively, and $\beta$ represents the loading of stearic acid in the composites. The crystallinity of stearic acid in the $\mathrm{SA} / \mathrm{SC}_{\mathrm{hc}}(99.78 \%)$ was clearly higher than in the $\mathrm{SA} / \mathrm{SC}_{\mathrm{wt}}(92.35 \%)$. The stearic acid in the $\mathrm{SA} / \mathrm{SC}_{\mathrm{hc}}$ had a higher $E_{e f}\left(189.78 \mathrm{~J} \mathrm{~g}^{-1}\right)$ than the $\mathrm{SA} / \mathrm{SC}_{\mathrm{wt}}\left(175.64 \mathrm{~J} \mathrm{~g}^{-1}\right)$. In this experiment, the loading of stearic acid in $\mathrm{SA} / \mathrm{SC}_{\mathrm{wt}}$ is higher than that in $\mathrm{SA} / \mathrm{SC}_{\mathrm{hc}}$, but the latent heat of phase change in $\mathrm{SA} / \mathrm{SC}_{\mathrm{hc}}$ is higher than $\mathrm{SA} / \mathrm{SC}_{\mathrm{wt}}$, and the crystallinity of stearic acid in $\mathrm{SA} / \mathrm{SC}_{\mathrm{hc}}$ is also higher than in $\mathrm{SA} / \mathrm{SC}_{\mathrm{wt}}$. This is because the mineral composition in stone coal is complex, and the adsorption of components in $\mathrm{SC}_{\mathrm{wt}}$ may affect the stearic acid molecules, reducing the regularity of stearic acid molecules and resulting in a decrease in crystallinity and a decrease in enthalpy.

\section{Conclusions}

The mineralogical and thermal storage characteristics of two types of stone coal $\left(\mathrm{SC}_{\mathrm{wt}}\right.$ and $\mathrm{SC}_{\mathrm{hc}}$ ) were investigated by XRF, XRD, FTIR, TGA-DTA, reflected light microscopy, thermal conductivity, and DSC. The content of $\mathrm{V}_{2} \mathrm{O}_{5}$ was $1.46 \mathrm{wt} . \%$ and $0.9778 \mathrm{wt} . \%$ for $\mathrm{SC}_{\mathrm{wt}}$ and $\mathrm{SC}_{\mathrm{hc}}$, respectively. The main mineral phase in the two samples was quartz, kaolinite, roscoelite, and goethite. The results of combining reflected light microscopy images and scanning electron microscopy of the stone coal show that most of the roscoelite in the stone coal is dispersed around the quartz. The thermal conductivity of $\mathrm{SC}_{\mathrm{wt}}$ and $\mathrm{SC}_{\mathrm{hc}}$ was $0.19 \mathrm{~W} \mathrm{~m}^{-1} \mathrm{k}^{-1}$ and $0.24 \mathrm{~W} \mathrm{~m}^{-1} \mathrm{k}^{-1}$, respectively. The $\mathrm{SA} / \mathrm{SC}_{\mathrm{wt}}$ and $\mathrm{SA} / \mathrm{SC}_{\mathrm{hc}}$ composites were prepared by impregnating $\mathrm{SA}$ into $\mathrm{SC}_{\mathrm{wt}}$ and $\mathrm{SC}_{\mathrm{hc}}$, respectively. The loading capacities of $\mathrm{SC}_{\mathrm{wt}}$ and $\mathrm{SC}_{\mathrm{hc}}$ for SA were $16.63 \%$ and $17.40 \%$, respectively. The latent heat value of $\mathrm{SA} / \mathrm{SC}_{\mathrm{hc}}$ $\left(33.02 \mathrm{~J} \mathrm{~g}^{-1}\right)$ was higher than that of SA/SC $\mathrm{wt}_{\mathrm{wt}}\left(29.21 \mathrm{~J} \mathrm{~g}^{-1}\right)$. The composite PCMs had good thermal stability under $300{ }^{\circ} \mathrm{C}$. Therefore, the $\mathrm{SC}_{\mathrm{hc}}$ is a potential candidate for thermal storage applications due 
to its higher thermal conductivity and loading capacity. The results can provide a base for preparing thermal storage materials from stone coal.

Supplementary Materials: The following are available online at http://www.mdpi.com/2075-163X/9/10/594/s1, Figure S1: The original EDS data (a) and BSE (b) of A1 in Figure 8; Figure S2: The original EDS data (a) and BSE (b) of A2 in Figure 8; Figure S3: The original EDS data (a) and BSE (b) of A3 in Figure 8; Figure S4: The original EDS data (a) and BSE (b) of A4 in Figure 8; Figure S5: The original EDS data (a) and BSE (b) of C1 in Figure 8; Figure S6: The original EDS data (a) and BSE (b) of C2 in Figure 8; Figure S7: The original EDS data (a) and BSE (b) of C3 in Figure 8; Figure S8: The original EDS data (a) and BSE (b) of E1 in Figure 8; Figure S9: The original EDS data (a) and BSE (b) of E2 in Figure 8; Figure S10: The original EDS data (a) and BSE (b) of E3 in Figure 8.

Author Contributions: Conceptualization, C.L.; methodology, C.L., W.L., and Z.H.; validation, C.L.; formal analysis, C.L.; investigation, C.L. and H.M.; data curation, H.M., B.X., B.Z., X.Z., and M.W.; writing-original draft preparation, H.M.; writing-review and editing, C.L., W.L., and J.C.; supervision, C.L.; project administration, C.L.; funding acquisition, C.L.

Funding: This work was supported by the National Natural Science Foundation of China $(51874047,51504041)$; the Training Program for Excellent Young Innovators of Changsha (kq1802007); the Fund for University Young Core Instructors of Hunan Province; the Outstanding Youth Project of Hunan Provincial Department of Education (18B148); and the Hunan Province 2011 Collaborative Innovation Center of Clean Energy and Smart Grid.

Conflicts of Interest: The authors declare no conflict of interest.

\section{References}

1. He, Z.; Li, M.; Li, Y.; Wang, L.; Zhu, J.; Meng, W.; Li, C.; Zhou, H.; Dai, L. Electrospun nitrogen-doped carbon nanofiber as negative electrode for vanadium redox flow battery. Appl. Surf. Sci. 2019, 469, 423-430. [CrossRef]

2. Yang, S.; Zhang, M.; Wu, X.; Wu, X.; Zeng, F.; Li, Y.; Duan, S.; Fan, D.; Yang, Y.; Wu, X. The excellent electrochemical performances of $\mathrm{ZnMn}_{2} \mathrm{O}_{4} / \mathrm{Mn}_{2} \mathrm{O}_{3}$ : The composite cathode material for potential aqueous zinc ion batteries. J. Electroanal. Chem. 2019, 832, 69-74. [CrossRef]

3. Cui, J.; Wu, X.; Yang, S.; Li, C.; Tang, F.; Chen, J.; Chen, Y.; Xiang, Y.; Wu, X.; He, Z. Cryptomelane-Type KMn8O16 as Potential Cathode Material—for Aqueous Zinc Ion Battery. Front. Chem. 2018, 6, 352. [CrossRef] [PubMed]

4. Jiang, Z.; Li, Y.; Zhu, J.; Li, B.; Li, C.; Wang, L.; Meng, W.; He, Z.; Dai, L. Synthesis and performance of a graphene decorated $\mathrm{NaTi2}\left(\mathrm{PO}_{4}\right)_{3} / \mathrm{C}$ anode for aqueous lithium-ion batteries. J. Alloys Compd. 2019, 791, 176-183. [CrossRef]

5. Yi, Z.; Huang, J.; Cen, C.; Chen, X.; Zhou, Z.; Tang, Y.; Wang, B.; Yi, Y.; Wang, J.; Wu, P. Nanoribbon-ring cross perfect metamaterial graphene multi-band absorber in $\mathrm{THz}$ range and the sensing application. Results Phys. 2019, 14, 102367. [CrossRef]

6. He, X.; Sun, Z.; Zou, Q.; Wu, L.; Jiang, J. Electrochemical Behavior of Co(II) Reduction for Preparing Nanocrystalline Co Catalyst for Hydrogen Evolution Reaction from 1-ethyl-3-methylimidazolium Bisulfate and Ethylene Glycol System. J. Electrochem. Soc. 2019, 166, D57-D64. [CrossRef]

7. Papanicolaou, C.; Kotis, T.; Foscolos, A.; Goodarzi, F. Coals of Greece: A review of properties, uses and future perspectives. Int. J. Coal Geol. 2004, 58, 147-169. [CrossRef]

8. Dai, S.; Guo, W.; Nechaev, V.P.; French, D.; Ward, C.R.; Spiro, B.F.; Finkelman, R.B. Modes of occurrence and origin of mineral matter in the Palaeogene coal (No. 19-2) from the Hunchun Coalfield, Jilin Province, China. Int. J. Coal Geol. 2018, 189, 94-110. [CrossRef]

9. Wang, L.; Sun, W.; Zhang, Q.-P. Recovery of vanadium and carbon from low-grade stone coal by flotation. Trans. Nonferrous Met. Soc. China 2015, 25, 3767-3773. [CrossRef]

10. Fang, S.; Xu, L.; Wu, H.; Tian, J.; Lu, Z.; Sun, W.; Hu, Y. Adsorption of Pb(II)/benzohydroxamic acid collector complexes for ilmenite flotation. Miner. Eng. 2018, 126, 16-23. [CrossRef]

11. Shu, K.; Xu, L.; Wu, H.; Fang, S.; Wang, Z.; Xu, Y.; Zhang, Z. Effects of ultrasonic pre-treatment on the flotation of ilmenite and collector adsorption. Miner. Eng. 2019, 137, 124-132. [CrossRef]

12. Huang, Z.; Cheng, C.; Liu, Z.; Zeng, H.; Feng, B.; Zhong, H.; Luo, W.; Hu, Y.; Guo, Z.; He, G.; et al. Utilization of a new Gemini surfactant as the collector for the reverse froth flotation of phosphate ore in sustainable production of phosphate fertilizer. J. Clean. Prod. 2019, 221, 108-112. [CrossRef] 
13. Wu, H.; Tian, J.; Xu, L.; Fang, S.; Zhang, Z.; Chi, R. Flotation and adsorption of a new mixed anionic/cationic collector in the spodumene-feldspar system. Miner. Eng. 2018, 127, 42-47. [CrossRef]

14. Fang, S.; Xu, L.; Wu, H.; Shu, K.; Xu, Y.; Zhang, Z.; Chi, R.; Sun, W. Comparative studies of flotation and adsorption of $\mathrm{Pb}(\mathrm{II}) /$ benzohydroxamic acid collector complexes on ilmenite and titanaugite. Powder Technol. 2019, 345, 35-42. [CrossRef]

15. Dai, S.; Zheng, X.; Wang, X.; Finkelman, R.B.; Jiang, Y.; Ren, D.; Yan, X.; Zhou, Y. Stone coal in China: A review. Int. Geol. Rev. 2018, 60, 736-753. [CrossRef]

16. Xie, T.; Liao, T.; Liu, C.; Xu, L.; Yang, J.; Zhu, Q.; Wang, J.; Zhang, X. Synthesis of multifunctional photocatalyst vanadium oxide/activated carbon via in situ utilization of stone coal ore. Ceram. Int. 2019, 45, 4934-4944. [CrossRef]

17. Wang, S.; Liu, G.; Hu, P.; Zhou, Y.; Ke, Y.; Li, C.; Chen, J.; Cao, T.; Long, Y. Largely lowered transition temperature of $\mathrm{V}_{2}$ /carbon hybrid phase change material with high thermal emissivity switching ability and near infrared regulations. Adv. Mater. Interfaces 2018. [CrossRef]

18. Zhang, Y.; Cen, C.; Liang, C.; Yi, Z.; Chen, X.; Li, M.; Zhou, Z.; Tang, Y.; Yi, Y.; Zhang, G. Dual-band switchable terahertz metamaterial absorber based on metal nanostructure. Results Phys. 2019, 14, 102422. [CrossRef]

19. Lv, Y.; Zhang, L.; Cheng, G.; Wang, P.; Zhang, T.; Li, C.; Jiang, Y.; He, Z.; Dai, L.; Wang, L. Preparation of carbon nanosheet by molten salt route and it's application in catalyzing $\mathrm{VO}^{2+} / \mathrm{VO}_{2}{ }^{+}$redox reaction. J. Electrochem. Soc. 2019, 166, A953-A959. [CrossRef]

20. Zhang, Y.; Bao, S.; Liu, T.; Chen, T.; Huang, J. The technology of extracting vanadium from stone coal in China: History, current status and future prospects. Hydrometallurgy 2011, 109, 116-124. [CrossRef]

21. Zhao, Y.; Zhang, Y.; Bao, S.; Chen, T.; Liu, X. Effect of Stone Coal Chemical Composition on Sintering Behavior during Roasting. Ind. Eng. Chem. Res. 2013, 53, 157-163. [CrossRef]

22. He, D.; Feng, Q.; Zhang, G.; Ou, L.; Lu, Y. An environmentally-friendly technology of vanadium extraction from stone coal. Miner. Eng. 2007, 20, 1184-1186. [CrossRef]

23. Wang, T.; Xu, L.; Liu, C.; Zhang, Z. Calcified roasting-acid leaching process of vanadium from low-grade vanadium-containing stone coal. Chin. J. Geochem. 2014, 33, 163-167. [CrossRef]

24. Bian, Y.; Zhang, Y.M.; Bao, S.; Zhao, Y. Analytical Method for Vanadium Occurrence State in Stone Coal and Corresponding Chemical Explanation. Min. Metall. Eng. 2013, 33, 62-70. [CrossRef]

25. Zeng, X.; Wang, F.; Zhang, H.; Cui, L.; Yu, J.; Xu, G. Extraction of vanadium from stone coal by roasting in a fluidized bed reactor. Fuel 2015, 142, 180-188. [CrossRef]

26. Hu, P.; Zhang, Y.; Huang, J.; Liu, T.; Yuan, Y.; Xue, N. Eco-Friendly Leaching and Separation of Vanadium over Iron Impurity from Vanadium-Bearing Shale Using Oxalic Acid as a Leachant. ACS Sustain. Chem. Eng. 2017, 6, 1900-1908. [CrossRef]

27. Gao, Z.; Fan, R.; Ralston, J.; Sun, W.; Hu, Y. Surface broken bonds: An efficient way to assess the surface behaviour of fluorite. Miner. Eng. 2019, 130, 15-23. [CrossRef]

28. Gao, Z.; Xie, L.; Cui, X.; Hu, Y.; Sun, W.; Zeng, H. Probing Anisotropic Surface Properties and Surface Forces of Fluorite Crystals. Langmuir 2018, 34, 2511-2521. [CrossRef]

29. Li, C.; Gao, Z. Tune surface physicochemical property of fluorite particles by regulating the exposure degree of crystal surfaces. Min. Eng. 2018, 128, 123-132. [CrossRef]

30. Tian, M.; Gao, Z.; Sun, W.; Han, H.; Sun, L.; Hu, Y. Activation role of lead ions in benzohydroxamic acid flotation of oxide minerals: New perspective and new practice. J. Colloid Interface Sci. 2018, 529, 150-160. [CrossRef]

31. Liu, S.; Yang, H. Composite of Coal-Series Kaolinite and Capric-Lauric Acid as Form-Stable Phase-Change Material. Energy Technol. 2015, 3, 77-83. [CrossRef]

32. Liu, S.; Yang, H. Stearic acid hybridizing coal-series kaolin composite phase change material for thermal energy storage. Appl. Clay Sci. 2014, 101, 277-281. [CrossRef]

33. Lin, H.; Li, G.; Dong, Y.; Li, J. Effect of $\mathrm{pH}$ on the release of heavy metals from stone coal waste rocks. Int. J. Min. Process. 2017, 165, 1-7. [CrossRef]

34. Li, C.; Xie, B.; Chen, J.; Chen, Z.; Sun, X.; Gibb, S.W. $\mathrm{H}_{2} \mathrm{O}_{2}$-microwave treated graphite stabilized stearic acid as a composite phase change material for thermal energy storage. RSC Adv. 2017, 7, 52486-52495. [CrossRef]

35. Li, C.; Xie, B.; Chen, J. Graphene-decorated silica stabilized stearic acid as a thermal energy storage material. RSC Adv. 2017, 7, 30142-30151. [CrossRef] 
36. Sun, W.; Wang, L.; Cao, X.; Liu, R.; Xu, L.; Han, H. Flotation technology and adsorption mechanism of vanadium extraction from stone coal. Chin. J. Nonferrous Metals 2012, 22, 2069-2074.

37. Li, M.; Liu, P.; Wang, F.; Cui, R. Study on Process Mineralogy of a Stone Coal Vanadium Ore in Hubei. Conserv. Util. Miner. Resour. 2013, 3, 41-46. [CrossRef]

38. Li, C.; Ouyang, J.; Yang, H. Novel sensible thermal storage material from natural minerals. Phys. Chem. Miner. 2013, 40, 681-689. [CrossRef]

39. Liu, J.; Zhang, Y.; Huang, J.; Liu, T.; Yuan, Y.; Huang, X. Influence of Mechanical Activation on Mineral Properties and Process of Acid Leaching from Stone Coal. Chin. J. Rare Met. 2014, 38. [CrossRef]

40. Fleet, M.E.; Liu, X. Carbonate apatite type A synthesized at high pressure: New space group (P3) and orientation of channel carbonate ion. J. Solid State Chem. 2003, 174, 412-417. [CrossRef]

41. Li, C.; Zeng, L.; Fu, H.; Chen, J.; He, J.; He, Z. Mineralogical and chemical characteristics of the lead-zinc tailing and contaminated soil from the mine tailing pond in Hunan Province (China). Physicochem. Probl. Miner. Process. 2017, 53, 1133-1147. [CrossRef]

42. Lin, H.; Wang, X.; Dong, Y.; Xu, X.; Zhang, Y. Bioleaching of Vanadium-Bearing Stone Coal by Heterotrophic Bacteria. Chin. J. Rare Met. 2017, 41. [CrossRef]

43. Li, C.; Fu, L.; Ouyang, J.; Tang, A.; Yang, H. Kaolinite stabilized paraffin composite phase change materials for thermal energy storage. Appl. Clay Sci. 2015, 115, 212-220. [CrossRef]

44. Wu, H.; Wei, C.; Fan, G.; Li, M.; Deng, Z.; Ge, H. Occurrence of Vanadium in High Carbon Stone Coal and Priority of Preparation Process. J. Kunming Univ. Sci. Technol. (Sci. Technol.) 2008, 33. [CrossRef]

45. Shutong, X.; Wen, S.; Yican, L.; Laili, J.; Shouyuan, J.; Okay, A.I.; Sengör, A.M.C. Diamond from the Dabie Shan Metamorphic Rocks and Its Implication for Tectonic Setting. Science 1992, 256, 80-82. [CrossRef]

46. van Panhuys-Sigler, M.; Trewin, N.H.; Still, J. Roscoelite associated with reduction spots in Devonian red beds, Gamrie Bay, Banffshire. Scott. J. Geol. 1996, 32, 127-132. [CrossRef]

47. Dai, S.; Xie, P.; Jia, S.; Ward, C.R.; Hower, J.C.; Yan, X.; French, D. Enrichment of U-Re-V-Cr-Se and rare earth elements in the Late Permian coals of the Moxinpo Coalfield, Chongqing, China: Genetic implications from geochemical and mineralogical data. Ore Geol. Rev. 2017, 80,1-17. [CrossRef]

48. Yang, G.; Yuan, Y.; Shen, Y.; Qu, Y. Analysis on thermal conductivity of cretaceous sandstone associated with microstructure. Coal Eng. 2015, 47, 82-85. [CrossRef]

49. Li, C.; Xie, B.; Chen, D.; Chen, J.; Li, W.; Chen, Z.; Gibb, S.W.; Long, Y. Ultrathin graphite sheets stabilized stearic acid as a composite phase change material for thermal energy storage. Energy 2019, 166, 246-255. [CrossRef]

50. Li, C.; Xie, B.; Chen, J.; He, Z.; Chen, Z.; Long, Y. Emerging mineral-coupled composite phase change materials for thermal energy storage. Energy Convers. Manag. 2019, 183, 633-644. [CrossRef]

51. Li, C.; Xie, B.; He, Z.; Chen, J.; Long, Y. 3D structure fungi-derived carbon stabilized stearic acid as a composite phase change material for thermal energy storage. Renew. Energy 2019, 140, 862-873. [CrossRef]

52. Li, C.; Zhang, B.; Xie, B.; Zhao, X.; Chen, J.; Chen, Z.; Long, Y. Stearic acid/expanded graphite as a composite phase change thermal energy storage material for tankless solar water heater. Sustain. Cities Soc. 2019, 44, 458-464. [CrossRef]

53. Li, C.; Wang, M.; Xie, B.; Ma, H.; Chen, J. Enhanced properties of diatomite-based composite phase change materials for thermal energy storage. Renew. Energy 2020, 147, 265-274. [CrossRef]

(C) 2019 by the authors. Licensee MDPI, Basel, Switzerland. This article is an open access article distributed under the terms and conditions of the Creative Commons Attribution (CC BY) license (http://creativecommons.org/licenses/by/4.0/). 